\title{
Internal carotid artery dissection which mimicry trigeminal neuralgia and cluster headache
}

\author{
Trigeminal nevralji ve küme başağrısını taklit eden internal karotid arter diseksiyonu
}

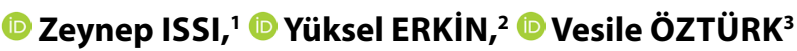

\begin{abstract}
Summary
Cervical artery dissection is an acute arterial disease. Although it is not a common disease, $40-60 \%$ cerebral infarction and $20-$ $30 \%$ transient ischemic attack could be seen. Thus, cervical artery dissection is important to recognize. Fifty-three years old female patient consulted with head, neck and face endaural pain that started after than spread directly left face half, effect of sometimes orbita and sometimes submaxillary area, occasionally accompanied by redness in the eye, extending from a few minutes to a few hours, it has been sharp and pulsatil characteristics and she never experienced before similar. Although not typical, with the initial diagnosis was trigeminal neuralgia and cluster headache $(\mathrm{CH})$, carbamazepine and tramadol treatment were started. The patient who had neck pain was severe during USG, and with atypical features was BT angioed to the brain and neck concerning differential diagnosis of the patient. It was detected profile compatible with dissection at left ICA proximal. In the literature, there are rare cases of ICA dissection mimicking $\mathrm{CH}$ and other trigeminal autonomic cephalalgias. A common recommendation in $\mathrm{CH}$ case reports is the need for neurovascular imaging in cases with atypical features.
\end{abstract}

Keywords: Cluster; dissection; internal carotid artery; trigeminal neuralgia.

\begin{abstract}
Özet
Servikal arteriel diseksiyon, akut arteriel bir hastalıktır. Sık rastlanan bir hastalık olmamakla birlikte $\% 40-60$ oranında serebral infarkt ve \%20-30 oranında geçici iskemik atak görülebileceğinden tanınması önemlidir. Elli üç yaşında kadın hasta, hastaneye geldiğinde dört gündür olan, başlangıçta kulak içinden başlayıp yayılan, daha sonra direk sol yüz yarısında, bazen orbitaya bazen de alt çene bölgesine vuran, zaman zaman gözde kızarıklığın da eşlik edebildiği, birkaç dakikadan birkaç saate uzayan, keskin ve zonklayııı vasıfta çok şiddetli, daha önce hiç yaşamadığı baş, yüz ve boyun ağrısı ile başvurdu. Tipik olmamakla birlikte trigeminal nevralji ve küme başağıısı ön tanıları ile karbamazepin ve tramadol başlanıldı. Boyun ağrısı ultrasonografi (USG) sırasında şiddetli olan ve atipik özellikleri olan hastaya ayırıcı tanı açısından beyin ve boyun bilgisayarlı tomografi (BT) Angio çekildi. Sol internal karotid arter (ICA) proksimalinde diseksiyon ile uyumlu görünüm saptandı. Literatürde nadir olarak küme başağrısını ve diğer trigeminal otonomik sefaljileri taklit eden ICA diseksiyonu vakaları vardır. Küme başağrısı vaka bildirimlerindeki ortak öneri ise atipik özellikler olan durumlarda nörovasküler görüntülemenin gerekliliğidir.
\end{abstract}

Anahtar sözcükler: Diseksiyon; internal karotid arter; küme; trigeminal nevralji.

\section{Introduction}

Cervical artery dissection is an acute arterial disease characterized by internal carotid artery (ICA) or hematoma on the vertebral artery wall. The incidence is $3 / 100000$. Although it is not a common disease, 40-60\% cerebral infarction and $20-30 \%$ transient ischemic attack could be seen. Thus, it is important to recognize. ${ }^{[1,2]}$

\section{Case Report}

Fifty-three years old female patient consulted with head, neck and face, endaural pain that started after then spread directly left face half, the effects of this was sometimes orbita and sometimes submaxilla area, occasionally accompanied by redness in the eye, extending from a few minutes to a few hours. It was sharp and had pulsatil characteristics and she

\footnotetext{
'Division of Algology, Department of Neurology, Dokuz Eylül University Faculty of Medicine, İzmir, Turkey 2Division of Algology, Department of Anesthesiology and Reanimation, Dokuz Eylül University Faculty of Medicine, İzmir, Turkey ${ }^{3}$ Department of Neurology, Dokuz Eylül University Faculty of Medicine, İzmir, Turkey

Submitted: 31.07.2017 Accepted after revision: 20.10.2017 Available online date: 18.10.2018
}

Correspondence: Dr. Zeynep Issı. Dokuz Eylül Üniversitesi Tıp Fakültesi, Nöroloji Anabilim Dalı, Algoloji Bilim Dalı, İnciraltı Yerleşkesi, İzmir, Turkey. Tel (Phone): +90 - 532 - 6407326 e-posta (e-mail): zzeyneptuncer@gmail.com () 2020 Turkish Society of Algology 
never experienced before. Her neurological examination was normal. Routine blood tests were within normal limits. Her history included diabetes mellitus, multinodular goiter, suspicion of trigeminal neuralgia on the right half of the face, and an old neck trauma story 20 years ago. She was using metformin, levothyroxine sodium and venlafaxine. She received a partial benefit from $10 \mathrm{~L} / \mathrm{min}$ oxygen therapy that was administered by the emergency department, followed by $100 \mathrm{mg}$ meperidine i.v. administrated that provided response partially. Brain CT and USG of carotid vertebral Doppler were normalized. Although not typical, trigeminal neuralgia and cluster headache anomalies and pain were mostly shortlived and effect on jaw. Thus, carbamazepine and tramadol treatment were started. She had a significant benefit from low-dose tramadol therapy. The patient who had neck pain was severe during USG and with atypical features was BT angioed to the brain and neck concerning differential diagnosis of the patient. It was detected profile compatible with dissection at left ICA proximal and spasm-related irregularities at distal. Distal current was present (Fig. 1 a-d). The underlying disease was thought to be fibromuscular dysplasia (FMD) because of the observation of tortiosis in bilateral cervical carotid arteries. Anticoagulant therapy was started. Control brain and neck CT angiography scanning the first month was similar to the previous one. Treatment of the patient with 100 mg acetylsalicylic acid was continued. The patient's consent was obtained for this study.

\section{Discussion}

The most frequent clinical presentation of cervical ICA dissections is cervical pain and headache which can be seen in approximately $67-77 \%$ of the cases
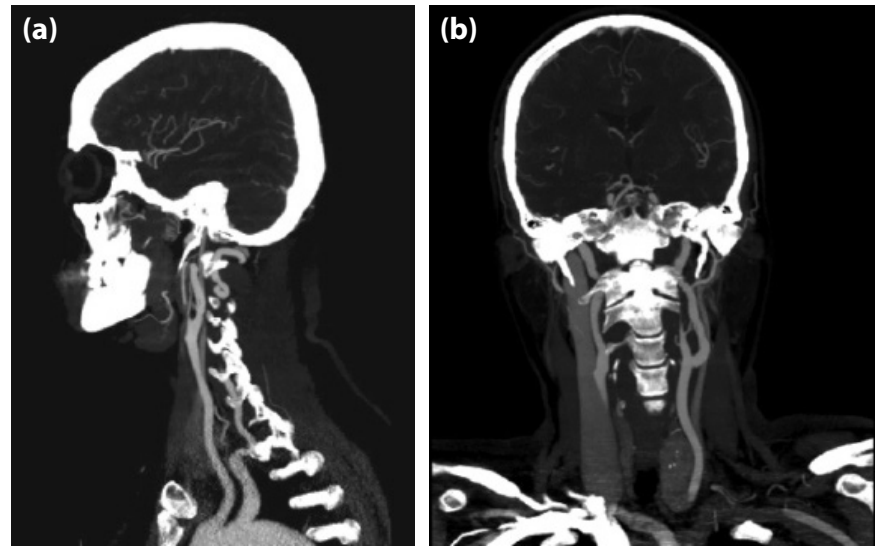

Figure 1. Internal carotid artery dissection. before brain and retinal ischemic events. Dissection is an important cause of ischemic cerebrovascular (CVO) events observed in young to middle age. In conjunction with this, it is escape the attention cause in sight $2 \%$ incidences of ischemic stroke, some reports stated an etiologic cause of $14-20 \%$ below age $50{ }^{[3,6,7]}$ Presentation with only headache, which is usually with the first and most frequent symptom, is rare. Headache is seen mostly in extracranial dissections and could have changeable features. Clinical findings could change depending on which localization of the dissection and which structures are adjacent. While frontotemporal, ipsilateral headaches are mostly associated with carotid dissections, neck and posterior headaches, dependent vertebrobasilar system dissections. Neck pain occurs quadrant of ICA dissection. Thunderclap headache and subarachnoid hemorrhages also become a differential diagnosis of dissections. ${ }^{[3,8]}$ In the literature, reported a case that was hemicrania continua phenotype and indomethacin that was beneficial, ${ }^{[1-3,6-8]}$ and there are rare cases of ICA dissection mimicking cluster headache and other trigeminal autonomic cephalagias. It has been thought that dissection pain might cause of parasympathetic symptoms mimicking headache autonomic phenomena of cluster headache with result in physiologically trigemino-autonomic responses. A common recommendation in cluster headache case reports is the need for neurovascular imaging in cases with atypical features. [4, 5, 9-11] Dissection pathophysiology is not clear. It is believed that in most cases, except for trauma, there is genetic underlying wall weakness. ${ }^{[1-3]}$ Treatment is controversial, but it is about preventing the development of thromboemboli in the area of dissection. It has been determined that antiplatelet alone or in combination CADISS study compared with anticoag-
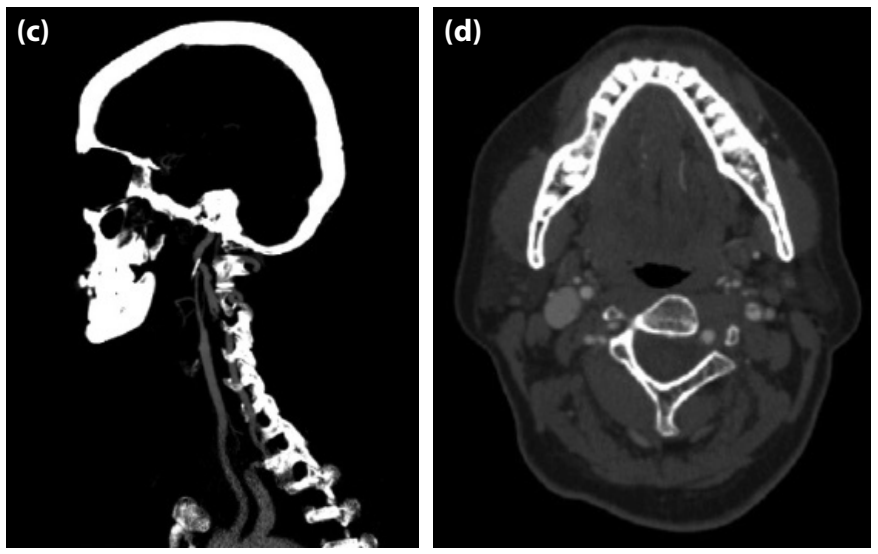
ulation therapy did not dominate each other in protection. Several studies have reported that the stent implant has a low complication and is successful. ${ }^{[3,}$ ${ }^{12,13]}$ To detect this situation, which can have many complications, initially you have doubts. It should be kept in mind differential diagnosis in atypical features of head and neck pain.

\section{Informed Consent: Written informed consent was obtained from the patient for the publication of the case report and the accompanying images.}

\section{Conflict-of-interest issues regarding the author- ship or article: None declared.}

\section{Peer-rewiew: Externally peer-reviewed.}

\section{References}

1. Mawet J, Debette S, Bousser MG, Ducros A. The Link Between Migraine, Reversible Cerebral Vasoconstriction Syndrome and Cervical Artery Dissection. Headache 2016;56(4):645-56. [CrossRef]

2 Akdal G. Servikoserebral Disseksiyonlar. In: Kumral E, editor. Santral Sinir Sisteminin Damarsal Hastalıkları. Güneş Tıp Kitabevleri; 2011. p. 623-8.

3. Sheikh HU. Headache in Intracranial and Cervical Artery Dissections. Curr Pain Headache Rep 2016;20(2):8. [CrossRef]

4. Tsivgoulis G, Mantatzis M, Vadikolias K, Heliopoulos I, Charalampopoulos K, Mitsoglou A, et al. Internal carotid artery dissection presenting as new-onset cluster Headache. Neurol Sci 2013;34(7):1251-2. [CrossRef]
5. Smit RA, Treurniet FE, Koppen H. Trigeminal Autonomic Headaches Caused by a Multinodular Goiter - A Case Report. Headache 2014;54(8):1369-70. [CrossRef]

6. Debette S. Pathophysiology and risk factors of cervical artery dissection:what have we learnt from large hospitalbased cohorts? Curr Opin Neurol 2014;27(1):20-8. [CrossRef]

7. Nagumo K, Nakamori A, Kojima S. Spontaneous intracranial internal carotid artery dissection: 6 case reports and a review of 39 cases in the literature. [Article in Japanese]. Rinsho Shinkeigaku 2003;43(6):313-21.

8. Silbert PL, Mokri B, Schievink WI. Headache and neck pain in spontaneous internal carotid and vertebral artery dissections. Neurology 1995;45(8):1517-22. [CrossRef]

9. Rigamonti A, lurlaro S, Reganati P, Zilioli A, Agostoni E. Cluster headache and internal carotid artery dissection: two cases and review of the literature. Headache 2008;48(3):467-70. [CrossRef]

10. Hardmeier $M$, Gobbi $C$, Buitrago $C$, Steck A, Lyrer $P$, Engelter $\mathrm{S}$. Dissection of the internal carotid artery mimicking episodic cluster headache. J Neurol 2007;254(2):253-4. [CrossRef]

11. Frigerio S, Bühler R, Hess CW, Sturzenegger M. Symptomatic cluster headache in internal carotid artery dissection- consider anhidrosis. Headache 2003;43(8):896-900. [CrossRef]

12. CADISS trial investigators, Markus HS, Hayter E, Levi C, Feldman A, Venables $G$, et al. Antiplatelet treatment compared with anticoagulation treatment for cervical artery dissection (CADISS): a randomised trial. Lancet Neurol 2015;14(4):361-7. [CrossRef]

13. Pham MH, Rahme RJ, Arnaout $O$, Hurley MC, Bernstein RA, Batjer $\mathrm{HH}$, et al. Endovascular stenting of extracranial carotid and vertebral artery dissections: a systematic review of the literature. Neurosurgery 2011;68(4):856-66. [CrossRef] 